\title{
Kulutusyhteiskunta ja sen kriitikot
}

\author{
Jukka Gronow
}

\section{Kuluttajat ja sosialismin loppu}

Vastikään ilmestyneessä artikkelissaan "Communism: a post mortem" (1990-91) puolalaissyntyinen jo pitkään Englannissa vaikuttanut sosiologi Zygmunt Bauman ehdottaa, että tärkeä syy Itä-Euroopan sosialististen valtioiden romahdukseen oli kulutusyhteiskunnan perustava yhteensopimattomuus sosialismin kanssa. Baumanin käsityksen mukaan sosialismi oli vielä suhteellisen kilpailukykyinen länsimaisen markkinatalouden kanssa mobilisoidessaan taloudellisia voimavaroja teollistamisen palvelukseen ja organisoidessaan taloudellista kasvua. Ainakin omasta mielestään se kykeni kilpailemaan siitä ideaalista, jota Bauman toisessa yhteydessä kutsuu "höyry- ja rautamodernin runsaudeksi" (ks. Bauman 1991, 268). Sitä kohtasivat vakavat ja ylitsepääsemättömät ongelmat niin pian kuin se joutui vastaamaan kansalaisten kasvaviin ja vähitellen eriytyviin kulutustavaroita koskeviin vaatimuksiin. Voisi myös sanoa, että sosialismi kykeni vielä suhteellisen tehokkaasti ja tasapuolisesti - jakeluongelmiksi kutsutuista ajoittaisista puutteista huolimatta - tyydyttämään ihmisten "perustarpeet". Se ei sen sijaan kyennyt hallitsemaan nopeasti kasvavia ja yhä monipuolisemmiksi muuttuvia tarpeita. Sitä tilannetta, johon tämä johti, voisi kutsua Agnes Hellerin tavoin "diktatuuriksi tarpeiden yli" (ks. Heller 1976; vrt. myös Heiskala 1985).

Itse asiassa Baumanin voi tulkita väittävän, että sosialismi on funktionaalinen niin kauan kuin kyse on tarpeiden logiikasta ja tarpeiden tyydyttämisestä. Se kykenee ainakin periaatteessa tyydyttämään sellaiset tarpeet, jotka ovat yleisiä ja periaatteessa universaaleja, kaikille ihmisille yhteisiä. Silloin kun se kohtaa modernin kuluttajan (Campbellin (1987) lanseeramaa ilmausta käyttääkseni: itse illusorisen hedonistin) yksilölliset mielihalut, jotka ovat periaatteessakin tyydyttämättömät, se on tuomittu epä- onnistumaan.

Moderni kuluttaja on toki yhtä lailla tyytymätön ja levoton niin sosialismissa kuin kapitalismissakin. Sosialismin erityisenä ongelmana vain oli se, että siinä kaikki kuluttajien kokemat pettymykset tulkittiin välittömästi hallituksen ja valtiovallan kyvyttömyydeksi hoitaa kunnolla taloutta (ks. myös Pastuhov 1991). Ja erityisesti silloin kun kuluttajan vaateet ovat yksilöllisiä ja moninaisia, valtio on aina tuomittu tuottamaan pettymyksiä "asiakkailleen". Läntiset markkinatalousyhteiskunnat ovat sen sijaan onnistuneesti siirtäneet vastuun yksilön elämästä ja tietoisuudesta tälle itselleen. Henkilökohtaiset frustraatiot ja katkeruudet on sekä hajautettu että epäpolitisoitu. (Ks. Bauman 1991, 268.) Tämä selittää myös sen miksi sosialistinen valtio kävi jatkuvaa ja epätoivoista ideologista sotaa esimerkiksi sellaisia pääasiassa nuorisokulttuurin ilmiöitä vastaan kuten leveät lahkeet, pitkät tukat ja rock-musiikki (ks. Bauman 1991, 287).

Samaan aikaan sosialistisissa yhteiskunnissa ón ollut kuitenkin juuri kulutukseen liittyviä piirteitä, jotka tekivät niistä varsin vakaita ja ovat estäneet sen että kuluttajien kokema tyytymättömyys kohdistuisi valtiovaltaan ja poliittiseen johtoon. Kuten puutetalouden tutkijat (vrt. Kornai 1982) ovat huomauttaneet, sosialistisen niukkuuden oloissa kuluttajan tärkeimmäksi ongelmaksi tulee tieto tavaran olemassaolosta ja pääsy sen luo (ks. Srubar 1991). Sillä joka kykenee hankkimaan tavaraa ja tietää mistä sitä saa on arvokasta pääomaa hallussaan. Raha on tällaisissa oloissa kyllä välttämätön muttei suinkaan riittävä tavaroiden hankkimisen edellytys.

Tällaisen niukkuuden oloissa syntyy varjotalous, joka koostuu pääasiassa hankintaverkostoista. Suuri osa valtion yritysten tuotteista "häviää" näihin verkkoihin ja katoaa epävirallisten jakelukanavien kautta. Tällaiset verkostot saattavat perustua ystävyyteen ja sukulai- 


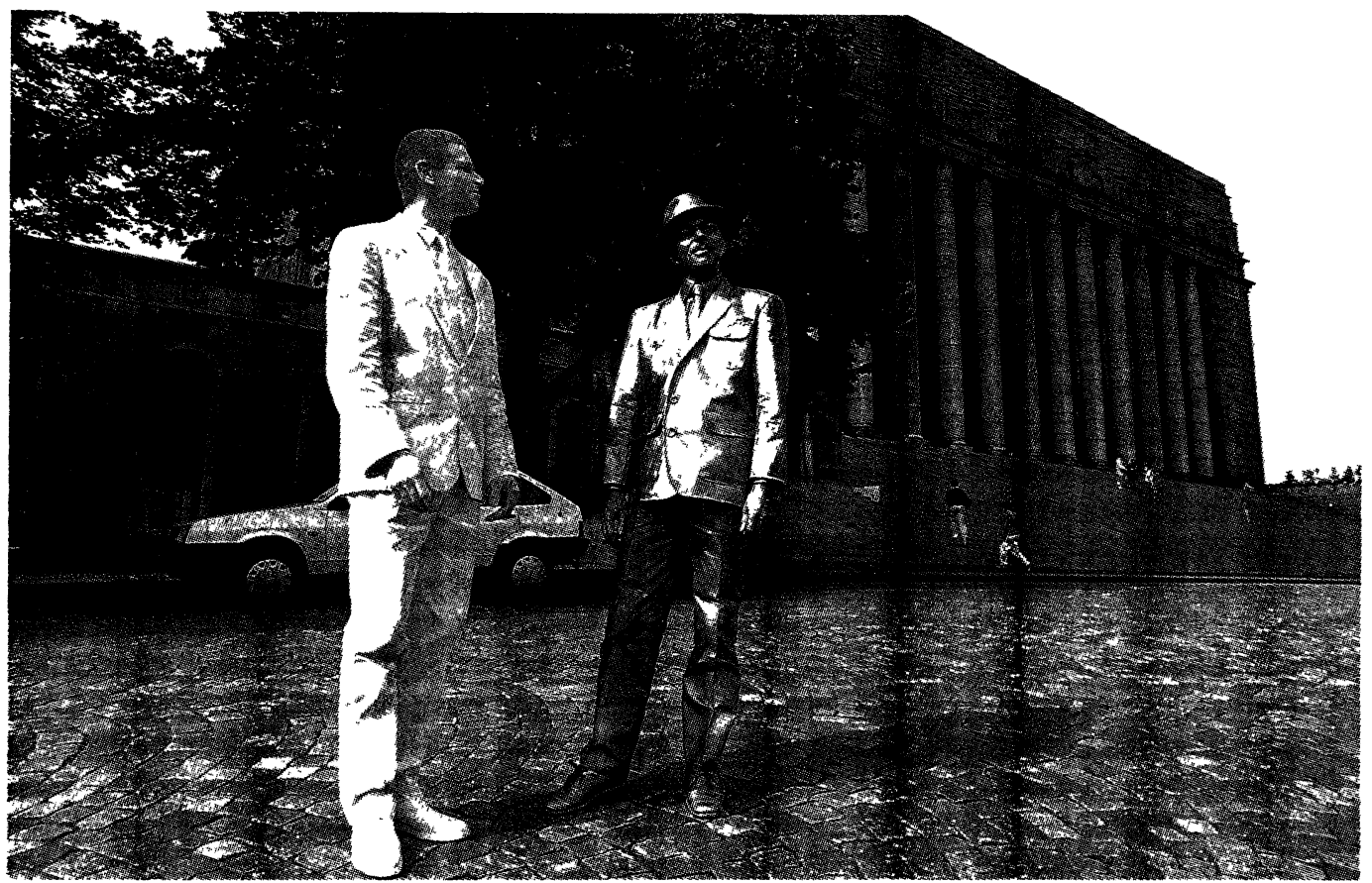

suuteen, mutta pääasiassa palveluiden ja vastapalveluiden synnyttämiin velvoitteisiin. Erityisen arvokkaita ja arvostettuja tällaisten verkostojen puitteissa ovat henkilöt, jotka toimivat jakelun avainkohdissa tai joiden joustava työaika tekee mahdolliseksi pimeiden hommien ja palvelusten suorittamisen.

Tällaisten verkostojen toimintaa voi hyvin verrata lahjainstituutioon. Ne sitovat jäsenensä vastavuoroisuuden luomaan velvollisuuksien verkkoon, joka ylläpitää niiden lojaalisuutta. Kuten Srubar toteaa niiden moraali on ressentimentin leimaamaa egalitarismia, joka vastustaa sellaisia muutoksia, jotka suosisivat yksilöllisiin suorituksiin perustuvia palkintoja. Ne estävät niin ikään tehokkaasti uudenlaisen vahvan identiteetin muodostumisen. Sosialistisen yksilön identiteetti sitoutui siten vahvasti omaan "klaaniin" tai "sukuun". Se teki selvän eron "meidän" ja "muiden" välillä.

Mikäli Srubarin käsitys sosialistisista yhteiskunnista heimoihin jakautuneina massayhteiskuntina (ks. myös Gronow 1991c) pitää paikkansa, on syytä suhtautua varauksellisesti Baumanin edustamaan toiveikkuuteen, joka koskee kuluttajien tyytymättömyyttä entisiä sosialistisia yhteiskuntia mullistavana voimana. Koska kansalaisten mielissä muiden menestyminen ja korkeampi elintaso voi johtua vain joko niiden nauttimista poliittisista etuoikeuksista, väärinkäytöksistä tai korruptiosta, ja varakkuus voi olla vain vääryydellä hankittua, kuluttajien tyytymättömyys ei välttämättä kohdistu valtion talouspolitiikkaan tai hallintoelinten tehottomuuteen, vaan saattaa yhtä hyvin kanavoitua katkeruudeksi ja vihaksi erilaisia etuoikeutettu- 
ja tai sellaisiksi kuviteltuja ryhmiä kohtaan. Onhan taistelu korruptiota vastaan ollut neuvostopolitiikan pysyvä piirre jo kauan ennen perestroikaa.

\section{Kulutusyhteiskunnan kriitikot}

On tavallaan paradoksaalista, että viime vuosisadan lopulta lähtien länsimaisissa yhteiskunnissa on ollut varsin voimakas ja pysyvä kulttuurikriittinen suuntaus, joka on arvostellut modernia yhteiskuntaa juuri siitä sen ominaispiirteestä, joka nyt Baumanin mukaan on osoittautunut voitokkaaksi. Näiden kriitikoiden käsityksen mukaan moderni, kaupallinen yhteiskunta pakottaa ihmiset jatkuvasti ylittämään omat - luonnolliset - tarpeensa. Se luo keinotekoisia ja turhia tarpeita sekä - vanhahtavaa ilmausta käyttääkseni - luksuksen tarpeen. Kaupallinen yhteiskunta houkuttelee ihmisiä jatkuvasti kuluttamaan enemmän kuin he oikeastaan tarvitsisivat. Ja tästä seuraavat monet - elleivät sitten kaikki - modernin yhteiskunnan ongelmat. Eivät nämä kriitikot toki olleet niin naiiveja, että he olisivat ajatelleet tavallisten ihmisten jo elävän yltäkylläisyydessä. Paremminkin he näyttivät pelkäävän, että "luonnollisten" tarpeiden asettamien rajoitusten kerran murruttua, rajoitusten jotka käytännössä määräytyivät henkilön säätyaseman mukaan ja joita valtio oli jo pitkään, usein tosin huonoin tuloksin, nähnyt aiheelliseksi säädellä ylellisyyslaein, ihmisten tarpeille ja vaatimuksille ei ole enää lainkaan rajoja. Ihmiset muuttuvat tyydyttämättömiksi. He eivät koskaan ole tyytyväisiä siihen mitä he ovat tai mitä heillä jo on.

Nykyisistä kulutusta koskevista kriittisistä puheista voi tunnistaa erilaisia toisiinsa kietoutuneita historiallisia kerrostumia. Ensimmäinen ja vanhin kerrostuma koskee ylellisyyttä ja sen turmelevaa vaikutusta. Toisessa on kyse luonnollisista ja keinotekoisista tarpeista. Kol- mas koskee muodin turhuutta. Ylellisyyskulutuksella moralisointi on ollut tyypillistä konservatiivien parissa. Järkevästä kuluttajasta ja tarpeista taas ovat kantaneet huolta teknokraattiset asiantuntijat. Muodin arvostelu on taas ollut ominaista erilaisille radikaaleille sosiaalireformisteille. Tästä ovat esimerkkeinä vaikkapa varhainen naisasialiike reformipukuineen tai nykyinen radikaalivihreä kierrätysasuineen. Juuri muoti on tällaisten liikkeiden piirissä saanut usein luvan edustaa sosiaalisten roolien tai instituutioiden mykkää pakkoa.

Olen eräissä viimeaikaisissa kirjoituksissani (Gronow 1990, 1991a, 199lb) identifioinut samantapaisen kulutusta koskevan kriittisen argumentaatiotavan alueilta, jotka ainakin ensisilmäyksellä näyttäisivät olevan toisistaan riippumattomia. Tämän argumentaatiotavan mukaan kaupallista yhteiskuntaa ei kritisoida siitä, että se jättäisi jäsentensä keskeiset tarpeet tyydyttämättä vaan päinvastoin siitä, että se pakottaa heidät ylittämään omat tarpeensa. Tällainen kritiikin tapa oli varsin yleinen etenkin vuosisadan vaihteessa eri aloja koskevissa keskusteluissa ja sitä voisikin luonnehtia varhaiseksi kulutusyhteiskuntaa koskevaksi kriittiseksi diskurssiksi.

Sen voi tunnistaa syntymässä olevan ravitsemustieteen yrityksistä ymmärtää ylensyönnin ja terveellisen ravinnon ongelmaa. Sen voi samoin tunnistaa erilaisista demokraattisista taidereformiohjelmista ja taideteollisuutta koskevasta esteettisestä keskustelusta, jotka propagoivat sellaista teollista muotoilua, joka eliminoisi kaiken - tarpeiden tyydytyksen kannalta turhan tai väärän - koristeellisuuden teollisuustuotteista. Tämä Art Industriel -liike oli myös Art Social -liike: se pyrki demokratisoimaan kulutusta ja lakkauttamaan turhan ylellisyyden pyrkimällä tyydyttämään ensisijaisesti niitä tarpeita, jotka ovat yhteisiä kaikille ihmisille. Samoihin aikoihin monet sosiaalireformistiset pamfletistit ja yhteiskuntateoreeti- 
kot käsittivät sosiaalisten ongelmien johtuvan siitä, että väärät ja keinotekoiset tarpeet ja halut hallitsivat ihmisten toimintaa. Kunhan ihmiset vain oppisivat säätelemään tarpeitaan ja tunnistamaan oikeat, aidot tarpeensa, he eivät ainoastaan kykenisi elämään tyydyttävämpää elämää vaan - niin kuin varhaiset utopistisosialistit ajattelivat - voisivat päästä eroon niin rahasta, pääomasta kuin yksityisomaisuudestakin ja niiden yhteisöä korruptoivasta vaikutuksesta.

Näistä kritiikeistä varmasti tunnetuin on alan eräänlainen klassikko Thorstein Veblenin teos Theory of the Leisure Class (1961(1899)), jossa esitettiin teoria silmäänpistävästä tuhlauksesta ja kulutuksesta. Veblenin mukaan turha ja pröystäilevä kulutus palvelee sosiaalisen kohoamisen pyrkimystä: esittämällä rikasta kuluttaja pyrkii saamaan osakseen sosiaalista arvostusta. Tämä sittemmin statussymbolikoulukunnaksi ristitty ajatustapa on ollut varsin yleinen sekä yhdysvaltalaisessa kulttuurikritiikissä että markkinoijien ja mainosmiesten keskuudessa. Sen mukaan ihmisten välinen sosiaalinen kilpailu — tai "väärä sosiaalinen ylpeys" — on se tekijä, joka viime kädessä selittää ihmisten taipumusta hillittömyyteen ja omien tarpeidensa ylittämiseen.

\section{Jälkiteollinen yhteiskunta runsauden yhteis-} kuntana

Ainakin implisiittisesti Bauman näyttää olettavan, että joskus viimeisten 70 vuoden aikana, ehkäpä toisen maailmansodan jälkeen, länsimaisen kaupallisen yhteiskunnan kehityksessä on tapahtunut muutos tai kenties jopa jonkinlainen katkos. Varhaisessa teollisessa yhteiskunnassa kulutus orientoitui vielä ensisijaisesti tarpeiden mukaan, jotka olivat rajalliset joskin muuttuvat, kun taas nykyisessä yhteiskunnassa kuluttajan mielihaluilla ei ole lainkaan rajoja. Toisin sanoen, teollinen yhteiskunta ei ole muuttunut vain jälkiteolliseksi vaan myös mas- sakulutusyhteiskunnaksi. (Bauman puhuu tässä yhteydessä jopa postmodernista yhteiskunnasta.) Ja nämä muutokset ovat sitten tavalla tai toisella heijastuneet myös sosialistisiin valtioihin. Varhaisemmat kulutusyhteiskunnan kriitikot postuloivat usein samantapaisen käänteen paljon aikaisempaan eurooppalaisen yhteiskunnan kehitysvaiheeseen ja identifioivat sen niukkuuden voittamiseen. Toisaalta tämän kuluttajan, jonka ongelmana oli paremminkin ylensyöminen kuin nälkä, tarpeiden ajateltiin olevan kuitenkin vielä ylempien sosiaalisten kerrostumien tarjoaman esikuvan säätelemiä ja siinä mielessä rajallisia.

60- ja 70-lukujen jälkiteollisen yhteiskunnan utopioissa (ja niiden radikaaleissa kritiikeissä) kulutus ei näyttele kovin tärkeää osaa. Jälkiteollisen yhteiskunnan ajateltiin olevan niukkuuden tuolla puolen oleva runsauden yhteiskunta, jossa elintaso olisi korkea ja jossa ihmisillä olisi käytettävissään ratkaisevasti enemmän vapaata-aikaa mm. ostoksiin ja kuluttamiseen. Kuten Krishan Kumar on huomauttanut laajassa jälkiteollisten yhteiskuntien teorioita koskevassa katsauksessaan Prophecy and Progress $(1983,195)$ niukkuuden jälkeisen talouden ajatuksen jakoivat sekä kulutusyhteiskunnan radikaalit kriitikot, kuten Herbert Marcuse ja Christopher Lasch, sen teknokraattiset puolestapuhujat kuten Herman Kahn ja Anthony Wiener että ekologisesti suuntautuneet anarkistit kuten Murray Bookchin. He kaikki olivat yhtä mieltä siitä, että teollisten yhteiskuntien tuottavuuden voimakas kasvu oli luonut historiallisesti ainutlaatuisen tilanteen, runsauden ja paljouden aikakauden. Ensimmäistä kertaa ihmiskunnan historiassa pienen vähemmistön joutilaisuus ja kulttuuri ei lepää suuren enemmistön välttämättömän työn varassa. Keynesin 1930-luvulla esittämä ennuste oli siten käymässä toteen. Tämän historiallisen asiaintilan sosiaalisista ja kulttuurisista seurauksista sen sijaan oltiin eri mieltä. 
Kulutuksen suhteen jälkiteollisen yhteiskunnan visiot eivät olleet kovin täsmällisiä. Odotettuja muutoksia luonnehdittiin yleensä vain määrällisin termein: korkeammat reaalitulot, korkeampi elintaso, ja enemmän vapaata aikaa. Esimerkiksi vuonna 1967 Herman Kahn luokitteli kirjoituksessaan "Toward the Year 2000 " yhteiskuntia niiden väestön määrällä jaetun bruttokansantuotteen mukaan teollisiin ja jälkiteollisiin. Hänen käsityksensä mukaan teollisuusyhteiskuntia seuraisivat kehittyneet teolliset tai massakulutuksen yhteiskunnat, jotka taas kypsä jälkiteollinen yhteiskunta tulisi syrjäyttämään. Vuonna 1965 vain Länsi-Eurooppa ja USA - ja ehkä Japani - olivat saavuttaneet massakulutusyhteiskunnan tason, mutta jo vuoteen 2000 mennessä kaksitoista kansakuntaa saavuttaisi "selvästi jälkiteollisen asteen" ja yhdeksän muuta kolkuttelisi sen portilla (ks. Bell 1974, 460-461). Jälkiteolliseen yhteiskuntaan sisältyi ennen kaikkea lupaus kaikkien vapaa-ajan huomattavasta lisääntymisestä ja "runsauden taloudesta, joka kykenisi turvaamaan kaikkien kansalaisten mukavuuden ja taloudellisen turvallisuuden riippumatta siitä osallistuisivatko he toimintaan, jota tavallisesti pidetään työntekona" (lainattu Bellin (1974, 462) mukaan).

Kun lukee näitä 60-luvun utopioita, käy ilmeiseksi, että tavalla tai toisella niissä ajateltiin kulutuksen merkityksen kasvavan tulevaisuudessa muutoinkin kuin määrällisesti elintason kasvun myötä samalla, kun ihmisten ei enää tarvitsisi kantaa huolta jokapäiväisestä, aineellisesta toimeentulostaan. Mutta muutoin kulutuksen merkitys tulevaisuuden kulutusyhteiskunnassa jäi melko epämääräisten luonnehdintojen varaan. Voisipa melkein sanoa, että kulutus oli tärkeämpi kohde modernisaation kriitikoille (kuten Vance Packardille tai Herbert Marcuselle) kuin sen puolestapuhujille (ks. Nava 1991). Samanlainen tilanne näyttää olevan myös uudemmissa modernisaatiotutkimuksis- sa, joista tyypillisenä esimerkkinä voisi käyttää Etzioni-Halevyn teosta Social Change (1981). Etzioni-Halevyn mukaan ihmiset elivät ennen teollistumista lähellä toimeentulorajaa. Sen jälkeen reaalipalkat ovat nousseet merkittävästi ja lähes yhtäjaksoisesti, minkä seurauksena myös elin- ja kulutustaso on noussut dramaattisesti. Mutta itse kulutustavoissakin on tapahtunut muutoksia. Tarkemmin sanoen: "Kulutusmenoissa on tapahtunut huomattava kestokulutustavaroiden suhteellisen osuuden kasvu, joka koskee niin uuneja kuin jääkaappeja ja ompelukoneitakin." (Etzioni-Haleyi 1981, 105) Tätä luetteloa voisi hyvin jatkaa autoilla, TV-laitteilla, videolaitteilla, CD-soittimilla jne. Johtopäätöksenään Etzioni-Halevy toteaa $(1981,105)$ suoraviivaisesti, että "länsimaista on todella tullut yltäkylläisiä".

Daniel Bell on harvinainen poikkeus jälkiteollisen yhteiskunnan teoreetikoiden joukossa tässä niin kuin monessa muussakin suhteessa. Juuri hän muotoili terävämmin kuin moni muu runsauden yhteiskunnan dilemman. Bellin (1974) mukaan runsauden yhteiskunnasta voidaan puhua vain erittäin rajoitetussa merkityksessä: nälän ja sairauden ongelmat ovat nyt ratkaistavissa. Mutta kuten Bell myös esitti, ainoastaan perustarpeet ovat tyydytettävissä ja vain tässä mielessä "runsauden mahdollisuus on todellinen". Mikään talous tai yhteiskunta ei muutoin kykene ratkaisemaan niukkuuden ongelmaa. Kuten Bell toteaa, suhteessa haluihimme ja pyyteisiimme resurssimme tulevat aina olemaan niukat. 'Taloustieteilijä' Bellille runsaus ei merkitse sitä, että esineitä olisi enemmän vaan sitä, että ne ovat halvempia. Runsaus tai yltäkylläisyys on siten aina suhteellinen tila.

Bellin The Coming of the Post-Industrial Society -teos (1974) sisältää myös hauskoja pohdiskeluja siitä, miten kulutuksen kasvu ja kestokulutustavaroiden hankkiminen saattaa myös johtaa vapaa-ajan niukkuuteen. Kotoisen esimerkin ottaakseni: ihmisen, jolla on sekä 
purjevene, kesämökki, golfmailat, tennismaila että laskettelusukset täytyy pitää kiirettä ehtiäkseen kuluttaa (merkityksessä: käyttää) mitään näistä tavaroistaan. Semminkin kun niiden oikea kuluttaminen edellyttää harjaannusta ja usein suorastaan koulutusta. Viimeksimainittuun, etenkin bourdieulaisessa skeemassa tärkeään seikkaan Bell ei tosin kiinnitä huomiota.

Kaiken kaikkiaan jälkiteollisen yhteiskunnan teoreetikoiden pohdinnoista näyttää olevan vaikeaa löytää selkeitä kriteereitä, joiden perusteella olisi oikeutettua puhua jostakin uudesta kulutusyhteiskunnan aikakaudesta. Tämä toki johtuu itse tarkastelutavan luonteesta: kyse on modernisaatioteorioista, joissa yhteiskunnallista kehitystä tarkastellaan ensi sijassa taloudellisen kasvun määrittämin määrällisin suurein. Silti tuntuisi Baumanin tavoin luontevalta olettaa - niin kuin jälkiteollisen yhteiskunnan visioissakin useimmiten ainakin implisiittisesti tehdään — että toisen maailmansodan jälkeen USA:ssa ja Länsi-Euroopan maissa kulutuksen merkityksessä ja luonteessa on tapahtunut jonkinlainen laadullinenkin muutos tai hyppäys.

\section{Kulutusyhteiskunta muodin yhteiskuntana}

Monesti ajatellaan, että modernin kuluttajan toimintaorientaatio tai dispositio on todellisuudessa on ehkä ratkaisevastikin muuttunut. On syntynyt uusi hedonistinen kuluttaja, jonka orientaatiota ei enää määrää "tarpeiden talous" vaan "halun ja unen tai unelmien talous", ja jota luonnehtii ensisijaisesti jonkin uuden ja vielä kokemattoman kaipuu. Luonnehtiessaan uutta keskiluokkaansa hedonistisen kulutuseetoksen kantajaksi Pierre Bourdieu (1984, 365-372) puolestaan korostaa sitä, että tämä haluaa kaiken heti ja mahdollisimman vähin kustannuksin. Sen etiikka on hauskanpidon etiikkaa. Tämän uuden konsumeristisen eetoksen on usein amerikkalaisessa traditiossa ajateltu johtuvan viime kädessä joko perheen tunnetalouden muutoksista tai olevan seurausta itse taloudellisen kasvun aiheuttamasta vapaa-ajan korostumisesta ja siitä seuraavasta työetiikan eroosiosta.

On kuitenkin olemassa toinenkin tapa lähestyä tätä kulutusyhteiskunnan luonnehdinnan ongelmaa, johon lähtökohtia tarjoavat ennen kaikkea Georg Simmelin muotia koskevat tarkastelut (Simmel 1986, ks. myös Noro 1991). Kuten tiedetään, muotimekanismi ei ole Simmelille tärkeä vain modernin kokemuksen kannalta. Se mahdollistaa myös sosiaalisen erottautumisen ja tarjoaa siten - vaikkakin vaatimattoman - turvapaikan yksilöllisyydelle suojaten sitä rahan pelottavalta, tasoittavalta vaikutukselta. Se auttaa kaiken lisäksi ainakin tentatiivisesti hallitsemaan sitä jännitettä, joka modernissa yhteiskunnassa syntyy tasa-arvon ja erilaisuuden, negatiivisen ja positiivisen vapauden periaatteiden välille.

Renate Mayntzin ja Birgitta Nedelmannin (1987) mukaan Simmelin analysoima muoti on eräs esimerkki itsedynaamisista sosiaalisista prosesseista (eigendynamishce soziale Prozesse). Tällaisille prosesseille on tyypillistä, että ne pitävät itse itsensä jatkuvassa liikkeessä ilman mitään niille ulkoista syytä. Prosessin "kantajien" eli sosiaalisten toimijoiden kannalta asiaa tarkasteltuna kyse on siitä, että näitä toimijoita toimintaan ajavat motivaatiot syntyvät ja vahvistuvat tämän saman prosessin kuluessa. Tällaisille prosesseille on myös luonteenomaista, että niitä on vaikea hallita tai suunnitella, koska ne nimenomaan toteutuvat riippumatta yksittäisen toimijan tahdosta ja usein jopa hänen tahtoaan vastaan. Yksittäisen toimijan kannalta on kyse eräänlaisesta sosiaalisesta pakosta, "näkymättömästä kädestä". (Ks. Mayntz ja Nedelmann 1987, 648-651.)

Muoti, sellaisena kuin Simmel sen tunnisti, on tyypillisesti tällainen itsedynaaminen prosessi. Simmelin käsityksen mukaan muodissa 
on kyse jatkuvasta sosiaalisen samastumisen ja erottautumisen vuorottelusta. Yksilöiden toimintaa ohjaa kaksi toisiinsa nähden vastakkaista tavoitetta. Toisaalta he haluavat integroitua ryhmään, mikä johtaa jäljittelemiseen, toisaalta taas he haluavat erottautua muista ja tulla esiin omina yksilöinään, mikä johtaa uudistuksiin. Muodin itsedynaamisuus liittyy nyt siihen, että nämä samastumisen ja erottautumisen vaiheet seuraavat välttämättä toisiaan ja synnyttävät toisensa: uutuus, jonka kaikki ovat jo omaksuneet, ei enää ole uutuus, ja sen tilalle on taas tuotava jotakin muuta uutta. Innovaatio ja imitaatio seuraavat toisiaan antaen aina sysäyksen uuteen innovaation ja imitaation sykliin. Muotikaruselli pyörii. (Ks. Mayntz ja Nedelmann 1987, 654.)

Mayntzin ja Nedelmannin Simmelin käsityksen perusteella kuvailema muotikaruselli ei kuitenkaan täytä tiukasti ottaen kaikkia heidän itsensä esittämiä itsedynaamisten prosessien kriteereitä. Vaikka toimijoiden motiivit siinä mielessä syntyvät itse prosessissa, että imitaatio antaa aina sysäyksen uudelle erottautumisen vaiheelle ja tyyli-innovaatiolle, eivät itse erottautumisen ja samastumisen sosiaalisten perusmotivaatioiden synty ja esiintyminen selity tuolla prosessilla. Ne näyttävät kuuluvan Simmelin katsannossa itse ihmisluonnon sosiaalisuuteen.

Mayntzin ja Nedelmannin tulkinnan mukaan muodissa kiehtoo siihen liittyvä "uusi". Mitä nopeammin karuselli pyörii, sitä kiehtovampi se on. Muiden itsedynaamisten prosessien tavoin tällaisilla usein toistuvilla toimintatavoilla on kuitenkin taipumus formalisoitua ja rutinoitua. Kerran institutionalisoiduttuaan muoti tulee ainakin osittain riippumattomaksi yksilöiden erottautumis-ja jäljittelyhalusta ja ylipäätään yksilöllisistä motiiveista. Muoti muistuttaa tällöin formaalia skeemaa. Kun esimerkiksi vaatemuodin vaihtelut olivat aiemmin yksilöiden sosiaalisen toiminnan tahaton sosi- aalinen seuraus, toimijat oppivat vähitellen tunnistamaan tällaisen mekanismin olemassaolon. Muotia ei kukaan alunperin tietoisesti synnytä, vaan se syntyy tavallaan muita tarkoitusperiä ajavan sosiaalisen toiminnan sivutuotteena. Nyt itse muodin luomisesta tulee - muodin tekijöiden ja myyjien - toiminnan motiivi. Muotiteollisuuden vaikutuksesta muodista voi tulla sosiaalinen pakko ja vaihtelunhalusta velvollisuus. Tämä saattaa Mayntzin ja Nedelmannin mukaan johtaa reaktioon: muotivaatteiden sijaan valitaankin jokin tavanomainen vaateparsi. Kuluttajat toisin sanoen kieltäytyvät jatkuvista uudistuksista ja tyytyvät vain vanhaan ja tuttuun. (Mayntz ja Nedelmann 1987, 654.)

Tässä muodin vastareaktiota koskevassa esimerkissä näyttäisi olevan kyse reagoimisesta kahteen eri asiaan. Toisaalta siihen, että kuluttaja ei halua, että mainostajat ja markkinoijat syöttävät ja tuputtavat hänelle uutuuksia, jolloin häneltä itseltään viedään kokonaan keksimisen ilo ja itsenäisen makuvalinnan mahdollisuus. Toisaalta taas siinä saattaisi olla kyse myös toisesta, teoreettisesti kiinnostavammasta ilmiöstä: voisihan ajatella, että kuluttaja väsyy muodin sisyfostyöhön. Mutta näin voisi käydä vain silloin, jos muoti palaisi ikuisesti samana. Tällöin uusi ei olisikaan uutta, eikä se sellaisena viehättäisi ja viettelisi. Simmeliläisittäin voisi kai sanoa, että ärsykkeitä voi olla liikaa ja ne voivat vaihtua liian tiuhaan, tai sitten niitä voi olla liian vähän ja ne vaihtuvat liian harvakseltaan. Edellinen johtaa ärtymiseen ja vetäytymiseen, jälkimmäinen tylsistää.

\section{Muodin ambivalenssit}

Mikä sitten olisi muodin vastakohta, anti-muoti. Mayntzin ja Nedelmannin mukaan se olisi lähinnä univormu, kaikille yhteinen asu. Periaatteessa se voisi kuitenkin olla myös kunkin ihmisen täysin yksilöllinen vaateparsi. Univormua näyttävät rakastavan järjestystä ja järkeä 
kaipaavat, täydellistä yksilöllisyyttä taas konformismia pelkäävät. Kumpikin vaihtoehto on yhtä mahdoton sekä modernin yhteiskunnan että yksilön kannalta. Ensimmäinen edellyttäisi täydellistä yhdenmukaisuutta, jälkimmäinen taas tekisi kaikista lähes täysin erillisiä yksilöitä, joita juuri mikään sosiaalinen side ei yhdistäisi. Kuten yksilön oli Rousseaun mielestä elettävä sosiaalisesti eristyksissä oppiaaksen tunnistamaan omat luonnolliset tarpeensa, muodin vältteleminen edellyttää myös sosiaalisen kanssakäymisen rajoittamista.

Kuten Arto Noro (1991, 110-113) on huomauttanut, anti-muoti ei ole ainoa eikä edes uskottava reaktio moderniin muotimekanismiin liittyvään sen enempää ylikiihtymiseen kuin toiston uhkaankaan. Kuten retromuodit ovat opettaneet (ks. myös Matthiesen 1988) muoti ei ole sen enempää aina ehdottoman samaa kuin ehdottoman uuttakaan. Silloinkin kun kyse on vanhan toistosta, tämä vanha ei ole koskaan täysin samaa vaan se esiintyy vähintäänkin jo uudessa yhteydessä. Näin se voi myös lisätä historiantajuamme ja tehdä suhdettamme muotiin refleksiivisemmäksi. Vastaus muotimekanismin pakonomaisuuteen ja vaihtelun pakkoon on taas "kombinoiva itsensä stilisointi" (Noro 1991, 112) eli muodin tarjoamien eri elementtien vapaa ja luova yhdistäminen. Näin syntyvät huippuyksilölliset tyylit saattavat vuorostaan muodostua uuden muodin esikuviksi ja sellaisina stilisoinnin kohteiksi, kuten viimeaikainen vaatemuoti, joka ottaa mallinsa usein kadun moderneilta "dandyiltä", on osoittanut. Muoti synnyttää ja uudistuakseen jopa edellyttää jatkuvaa itsekritiikkiä ja innovatiivisuutta. Juuri muodin vastareaktiot voivat tuottaa uusia rinnakkaisia tyylejä ja niiden yhdistelmiä, joista uudet muodit valikoituvat.

Vaikka Mayntz ja Nedelmann ovatkin varovaisia arviossaan, he ovat kuitenkin taipuvaisia ajattelemaan muodin kaltaisten itsedynaamisten prosessien yleistyvän modernissa, funktio- naalisesti eriytyneessä yhteiskunnassa, jolle ovat lisäksi tyypillisiä tavoitteita koskevat ambivalenssit ja ristiriidat. Alustavasti voisi sanoa, että juuri muodin sekä ekstensio että intensio, sen toiminnan ulottuminen sekä yhä uusille aloille että sen vaikutuksen syveneminen monilla aloilla, on tyypillistä kulutusyhteiskunnalle. Kulutusyhteiskunta on siten muodin ja etenkin massamuodin (ks. Horowitz 1975) yhteiskunta. Muotisykli nopeutuu, uusi ja käyttökelpoinen muuttuu vanhaksi ja käyttökelvottomaksi yhä nopeammin. Uudet tyylit seuraavat toisiaan, eikä tällä muodilla ole mitään ulkoisia esikuvia. Tällainen yhteiskunta ei tunne turhan kulutuksen ongelmaa, sillä ei ole mitään muodille ulkoisia kriteereitä, jotka määrittäisivät, mikä on turhaa. Tällöin kulutusyhteiskunta on paremminkin jatkuvan niukkuuden kuin runsauden yhteiskunta, sillä siinä ei koskaan voi saada kyllikseen. Se edellyttää konsumeristista elämänasennetta, sillä yhä useammilla elämänaloilla on jatkuvasti tarjolla uutta ja erilaista. Moderni kuluttaja-hedonisti on muodin myöntäjä ja myötäilijä.

Baumanin alkuperäisen teesin sosialismin luhistumisesta voi nyt muotoilla uudelleen: ItäEuroopan sosialistiset maat luhistuivat, koska niissä ei ollut kehittynyttä muotimekanismia tai ne eivät ainakaan koskaan oppineet tulemaan toimeen sellaisen kanssa.

\section{Kirjallisuus}

Bauman, Zygmunt (1990-91): Communism: a post mortem. Praxis International 10: 3-4, s. 185-192.

Bauman, Zygmunt (1991): Modernity and Ambivalen$c e$. Cornell University Press, London.

Bell, Daniel (1974): The Coming of Post-industrial Society. Heinemann, London.

Bourdieu, Pierre (1984): The Distinction. Routledge\&Kegan Paul, London.

Campbell, Colin (1987): The Romantic Ethic and the Spirit of Modern Consumerism. Basil Blackwell, Oxford \& New York.

Etzioni-Halevy, Eva (1981): Social Change. The Advent and Maturation of Modern Society. Rout- 
ledge\&Kegan Paul, London.

Falk, Pasi (1990): Modernin hedonistin paradoksi. Sosiologia 27:2, s. 108-124.

Gronow,Jukka(1990):Mitä onhyvämaku? Sosiologia 27: 2, s. 95-107.

Gronow, Jukka (1991a): Kitsch, muoti ja maun turmelus. Synteesi 10:3, s. 77-93.

Gronow, Jukka (199b): Need, Taste and Pleasure: Understanding Food and Consumption. Teoksessa Fürst, E. ym. (toim.): Palatable Worlds. Sociocultural Food Studies. Solum, Oslo.

Gronow, Jukka (1991c): NL:n yleinen mielipide torjuu kapitalismin. Helsingin Sanomat 15. 11.1991.

Heiskala, Risto (1985): Vapauden ja välttämättömyyden valtakunnat - emansipaatio ja ekonomiakritiikki. Tutkijaliiton julkaisusarja 33. Helsinki.

Heller, Agnes (1976): The Theory of Need in Marx. Allison\&Busby, London.

Horowitz, R. T. (1975): From Elite Fashion to Mass Fashion. Archives Européennes de Sociologie 16: 2, s. 283-295.

Kornai, János (1982): Growth, Shortage and Efficiency. Basil Blackwell, Oxford.

Kumar, Krishan (1983): Prophecy and Progress. The
Sociology of Industrial and Post-industrial Society. Penguin Books, Harmondsworth.

Matthiesen, Ulf (1988): Outfit \& Ichfinish. Zur beschleunigten Wandlungstypik der gegenwertigen Bekleidungsmoden. Soziale Welt. Sonderband 6., s. 413-448.

Mayntz, Renate \& Nedelmann, Birgitta (1987): Eigendynamische soziale Prozesse. Anmerkungen zu einem analytischen Paradigma. Kölner Zeitschrift für Soziologie und Sozialpsychologie 39:4, s. 648-668.

Nava, Mica (1991): Consumerism Reconsidered: Buying and Power. Cultural Studies 5:2, s. 157-173.

Noro, Arto (1991): Muoto, moderniteetti ja 'kolmas'. TutkielmaGeorgSimmelin sosiologiasta.Tutkijaliitto, Jyväskylä.

Simmel, Georg (1986): Muodin filosofia. Odessa, Helsinki.

Srubar, Ilja (1991): War derreale Sozialismus modern? Versuch einer strukturellen Bestimmung. Kölner Zeitschrift für Soziologie und Sozialpsychologie 43:3, 415-432.

Veblen, Thorstein (1961): The Theory of the Leisure Class. Random House, New York. 